\title{
Alpine ecology, plant biodiversity and photosynthetic performance of marker plants in a nitrogen gradient induced by Alnus bushes
}

\author{
Rexha Kaltrina ${ }^{1}$, Bego Kristi ${ }^{2}$, Zyruku Dea', Shuka Lulezim² ${ }^{2}$ Husi René ${ }^{3}$, Schneller Jakob ${ }^{4}$ \\ and Bachofen Reinhard ${ }^{5^{*}}$ (1)
}

\begin{abstract}
Background: Alpine alder vegetation acts upon the nearby grass and dwarf shrub vegetation by the nitrogen supply from the symbiotic bacteria Frankia alni of Alnus viridis. This has been studied in two transects concerning plant distribution, plant diversity, nitrate concentration in soil and photosynthetic performance of specific marker plants.

Results: Away from the alder stand, a band of some meters was dominated by Calamagrostis varia which then was followed by alpine dwarf shrub vegetation. Nitrate in the soil showed a concentration decrease away from the alder stand leading to values near the detection limit in the dwarf shrub zone. Within these three zones, plant species were distributed according to their N-index, given in the ecological literature. Three dominant species, Calamagrostis varia, Rhododendron ferrugineum and Vaccinium myrtillus were examined at sites of different $\mathrm{N}$-availability in the horizontal transect for their photosynthetic performance, by measuring the prompt fluorescence, the OJIP named polyphasic rise of chlorophyll-a fluorescence. All three plant species showed signs of stress in the fluorescence rise kinetics at decreased nitrate availability. These are similar to other known stress effects such as faster reduction of the primary acceptor or an electron supply limitation on the donor site of photosystem II.
\end{abstract}

Conclusion: Prompt chlorophyll-a fluorescence data of the examined leaves in a natural vegetation system showed the effects of a decrease in the essential nutrient nitrogen and in a manner parallel to changes in plant diversity. The selected marker plants behaved differently towards decreasing nitrogen concentrations in soil.

Keywords: Alnus, Calamagrostis, Dwarf shrubs, Frankia, Plant frequency, N-indicator, Fast chlorophyll fluorescence, Nitrogen gradient

\section{Background}

Nitrogen is one of the main nutrients for plant growth and is considered to be the limiting factor for net primary production in terrestrial ecosystems [34, 35]. For high productivity in agriculture, nitrogen is supplied

\footnotetext{
*Correspondence: reinhard.bachofen@uzh.ch
}

${ }^{5}$ Dept. of Plant and Microbial Biology, University of Zürich, Zürich, Switzerland

Full list of author information is available at the end of the article as fertilizer in the form of nitrate or ammonium. In natural pristine environments nitrogen fixing bacteria, free living or as root symbionts, provide bound nitrogen in nitrogen-poor soil. In the alpine shrub and grass zones the concentration of available nitrogen is often low; although various nitrogen compounds may be imported through the atmosphere by wind or rain. Alnus viridis is an important component of the tall shrub vegetation in the subalpine and alpine areas. Due

(c) The Author(s) 2020. This article is licensed under a Creative Commons Attribution 4.0 International License, which permits use, sharing, adaptation, distribution and reproduction in any medium or format, as long as you give appropriate credit to the original author(s) and the source, provide a link to the Creative Commons licence, and indicate if changes were made. The images or other third party material in this article are included in the article's Creative Commons licence, unless indicated otherwise in a credit line to the material. If material is not included in the article's Creative Commons licence and your intended use is not permitted by statutory regulation or exceeds the permitted use, you will need to obtain permission directly from the copyright holder. To view a copy of this licence, visit http://creativeco mmons.org/licenses/by/4.0/. The Creative Commons Public Domain Dedication waiver (http://creativecommons.org/publicdomain/ zero/1.0/) applies to the data made available in this article, unless otherwise stated in a credit line to the data. 
to root symbiosis with the nitrogen-fixing Actinobacterium Frankia alni, the soil at these sites is enriched in plant-available nitrogen and a remarkable accumulation of biomass may be seen nearby. This suggests the presence of a nitrogen flow away from the alder zone into the neighboring grass and shrub zones. Thus, a clear change in plant composition and diversity away from the border of the Alnus tall forbs is often observed even with the naked eye.

In the Piora valley (Central Switzerland, Canton Ticino) such sites are found on the north- exposed slope of the Mottone, south of the Murinasca River. In an open area between Alnus bushes and trees a defined stripe of grasses (mainly Calamagrostis) is observed growing adjacent to the Alnus border (see Figs. 1,2). This grass vegetation is abruptly followed by dwarf shrubs, suggesting that sudden changes in nutrient supply might be the cause. It is known that nitrogen-species are washed out from the soil at Alnus-dominated sites [6] and from nitrogen-enriched forest [26]. Plant biodiversity changes along the nitrogen gradient. To quantify these observations, the plant composition and diversity were studied in a horizontal and a vertical transect perpendicular to the Alnus bushes. The effect on plant metabolism was studied by measuring the photosynthetic performance of selected dominating plant species at different sites in the $\mathrm{N}$-gradient.
In recent decades, chlorophyll- $a$ fluorescence techniques have been used to measure the fitness of or the stress upon plants caused by pollutants (e.g. ozone, [3]), but also by environmental climatic factors such as heat and drought, or the availability of nutrients. These techniques are non-invasive and rapid, and ideal for field measurements, as reviewed recently by Kalaji et al. [13]. After dark adaptation to obtain a fully oxidized acceptor site of photosystem II, a strong light flash increases chlorophyll- $a$ fluorescence from a minimal value at time $10 \mu \mathrm{s}$ $\left(\mathrm{O}=\mathrm{F}_{\mathrm{o}}=\right.$ initial fluorescence $)$ to a maximum at 0.3 to $1 \mathrm{~s}$ $\left(\mathrm{P}=\mathrm{F}_{\mathrm{m}}=\right.$ maximal fluorescence). When plotted in a logarithmic scale, this transient shows polyphasic kinetics, with steps at $2 \mathrm{~ms}$ (J-step) and $30 \mathrm{~ms}$ (I-step) (see kinetics in Fig. 5). This sequence has been named the OJIP-test. With a detailed analysis of it, specific information can be gained to estimate the vitality of plants $[30,31]$. The $F_{v} /$ $F_{m}$ value is frequently used in the literature, designating the maximum quantum yield of the photosystem II, $F_{v}$ being the variable fluorescence $\left(F_{m}-F_{o}\right)$. However, $F_{v} / F_{m}$ covers only primary photochemistry as originally discovered by Butler and Kitajiama [4]. This parameter therefore has been found to be relatively insensitive towards many metabolic changes in the plant induced by environmental effects. Several other parameters can be derived from the OJIP kinetics which seem to be more sensitive and more specific than the $\mathrm{F}_{\mathrm{v}} / \mathrm{F}_{\mathrm{m}}$ value (e.g. $[2,12,18,23$,

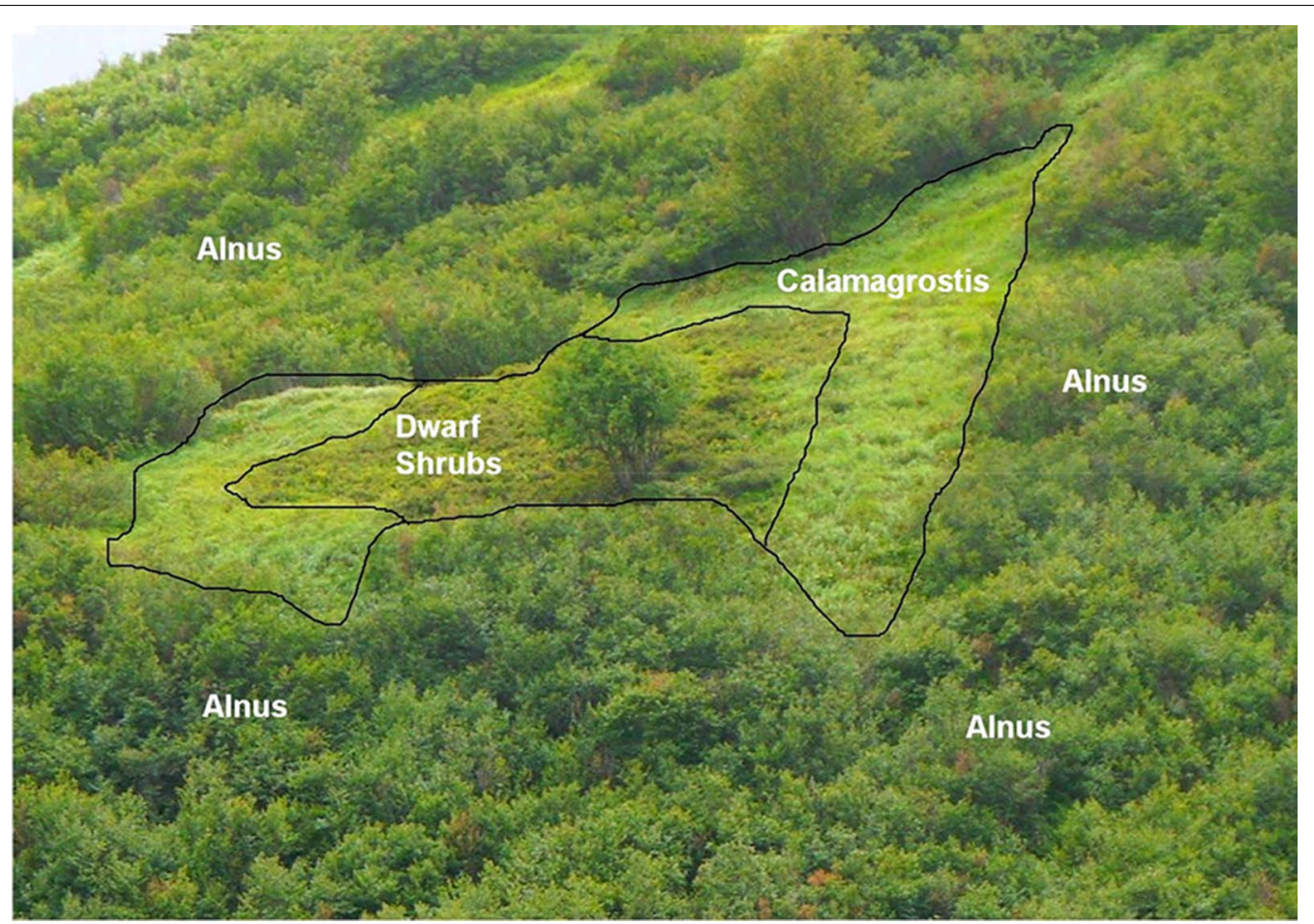

Fig. 1 Photo of the experimental site with the Alnus viridis zone, the Calamagrostis varia band and the dwarf shrub zone. (Photo: J. Schneller) 


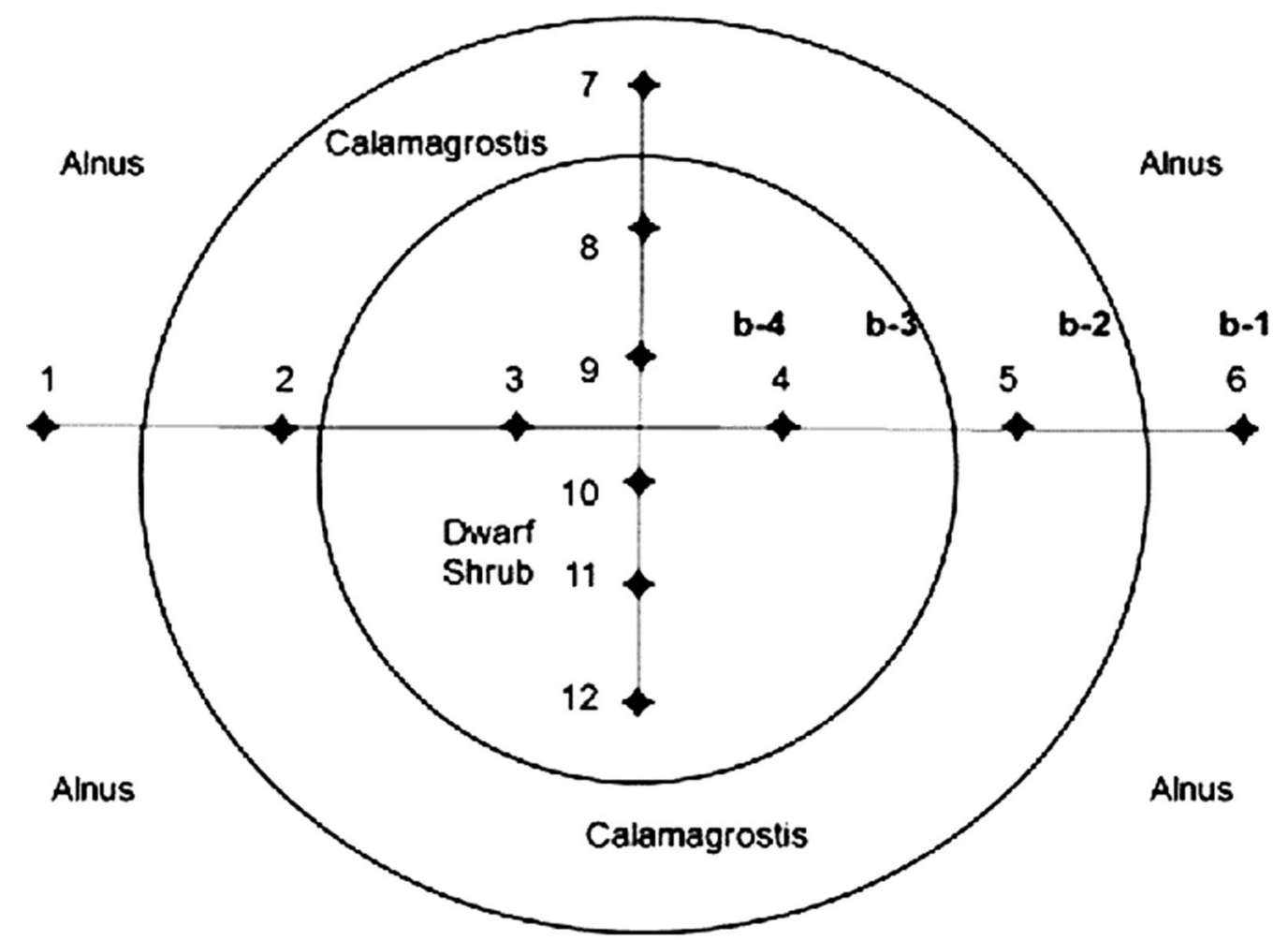

Fig. 2 Schematic drawing of the experimental site with the three main vegetation zones characterized by the dominant marker plants species Alnus, Calamagrostis and dwarf shrubs. The squares of $1 \mathrm{~m}^{2}$ used for floristic investigation are arranged as horizontal (1-6) and vertical (7-12) transects. The locations of the sampling of soil for nitrate determination and of the plant leaves for fluorescence measurements are labeled as b- 1 to b-4; b-5 is some $100 \mathrm{~m}$ away from Alnus trees in a dwarf shrub area

$24,36,37])$. The level of the minimum fluorescence $F_{o}$, the initial velocity of the fluorescence rise, or the J-point, the fluorescence level reached after $2 \mathrm{~ms}$ have been suggested as valuable markers. Such factors are pooled in the photosynthetic performance index PI. Thus the PI covers more information by combining primary photochemistry with dark reactions of the photosynthetic electron transport and the $\mathrm{CO}_{2}$-fixation downstream the charge separation in photosystem II. For a detailed discussion on the theory behind the OJIP-test see Strasser et al. [31] and Stirbet et al. [29].

In various crop plants, the OJIP-fluorescence induction kinetics is influenced not only by physical environmental stress, but also by the availability of various nutrients, among these nitrogen [19, 25, 33, 37, 38]. In controlled nitrogen fertilization experiments with a single plant species of same age and genetics, differences in photosynthetic performance related to nutrient concentration have been demonstrated. In this study we present the effect of different nitrogen availability in soil-produced by a natural gradient caused by nitrogen leaching from Alnus vegetation-on the photosynthetic performance of typical common plants in a natural alpine ecosystem.
These results correlate well with ecological changes in plant species distribution and biodiversity at these sites and with the empirically determined $\mathrm{N}$-index values in the literature.

\section{Results}

\section{Characterization of vegetation and environment}

The vegetation assessment demonstrates the change of species within their habitat along the two transects (see Fig. 2). Table 1 shows the floristic composition of the plant species in each of the 6 plots of the horizontal and the vertical transect with the semi-quantitative estimation of the plant frequency based on Braun-Blanquet [1]. The scaling runs from $1=$ very few to $6=$ dominant. Plant distribution was characterized by three clearly distinct zones with increasing distance from the Alnus vegetation, first a Calamagrostis belt $(1$ to $3,7,8)$ and then the dwarf shrub zone in the center (4, 5 and 9 to 12). These zones were easily distinguished by eye, using vegetation structure and the intensity of leaf color, even within the same species in different parts of the transect. Rhododendron ferrugineum was hardly found near the Alnus bushes, while Vaccinium myrtillus or Veratrum album 
Table 1 List of plants and their frequencies observed in the horizontal (sample 1-6) and vertical transect (sample 7-12)

\begin{tabular}{|c|c|c|c|c|c|c|c|c|c|c|c|c|c|}
\hline \multirow[t]{2}{*}{ Number of plots } & \multirow[t]{2}{*}{ L-val. } & \multicolumn{6}{|c|}{ Horizontal plots } & \multicolumn{6}{|c|}{ Vertical plots } \\
\hline & & 1 & 2 & 3 & 4 & 5 & 6 & 7 & 8 & 9 & 10 & 11 & 12 \\
\hline \multicolumn{14}{|l|}{ Species } \\
\hline Achillea macrophylla & 4 & & + & & & & & & & & & & \\
\hline Alnus viridis & 4 & 4 & & & & & 4 & & & & & & \\
\hline Athyrium distentifolium & 3 & & 2 & & & & & & & & & & \\
\hline Avenella flexuosa & 2 & & & & + & & & & + & + & + & 2 & + \\
\hline Calamagrostis varia & 2 & 1 & 1 & & & 2 & & 4 & & & & & \\
\hline Dryopteris dilatata & 3 & + & & + & & + & & + & & & + & & \\
\hline Festuca rubra & 3 & & & & & & + & & & + & & & \\
\hline Gentiana purpurea & 2 & & & & 1 & + & + & & & + & + & & \\
\hline Homogyne alpina & 2 & & + & & 1 & 2 & + & & + & & & + & \\
\hline Juniperus communis & 2 & & & & & + & & & & & & & \\
\hline Ligusticum mutellina & 3 & & + & & & & & & & & & & \\
\hline Lilium martagon & 3 & & + & & & & & & & & & & \\
\hline Luzula silvatica & 2 & & & & & & & & & & + & & \\
\hline Oxalis acetosella & 2 & + & 1 & + & 1 & & & 1 & + & + & + & + & + \\
\hline Phleum alpinum & 2 & & & & & & + & & & & & & \\
\hline Rhododendron ferrugineum & 2 & + & & 1 & 2 & 2 & + & & + & 2 & 3 & & 5 \\
\hline Solidago virgaurea & 3 & & & & & & + & & & & & & \\
\hline Sorbus aucuparia & 2 & & & & & + & & + & & & & & \\
\hline Vaccinium myrtillus & 2 & 1 & & + & 2 & 3 & 1 & & + & 1 & + & 3 & + \\
\hline Vaccinium uliginosum & 2 & & & & 3 & 2 & & & & 3 & 3 & 3 & \\
\hline Veratrum album & 4 & 1 & 4 & 1 & & 1 & 3 & 3 & 1 & & + & & + \\
\hline
\end{tabular}

The frequency of the species found is given following the cover abundance scale of Braun-Blanquet [1], ranging from $+: 2 \%, 1: 2-5 \%, 2: 5-25 \%, 3: 25-50 \%, 4: 50-75 \%$, 5: 57-100\%. L-val. = Landolt N indicator value Landolt et al. [17]

were spread over the whole transect. Besides Rhododendron, several genera such as Oxalis, Homogyne or Gentiana seemed to avoid sites close to the Alnus zone.

$\mathrm{N}$-indicator values [17] characterize the preference of a plant towards available nitrogen in soil. Combined with the frequency of species in each sample plot (given in column 1 of Additional file 1: Table S1), a N-indicator value for plant-available nitrogen at each site was calculated (see Additional file 1: Table S1). The mean of the indicator values of all species collected suggested the presence of a nitrogen gradient, with highest values in the surrounding Alnus zone (Fig. 3, plots 1, 2, 6, 7), then decreasing towards the open part, with the lowest values within the dwarf shrub area (plots 3, 4, 9-12). On the same basis the plant composition indicated that the $\mathrm{pH}$ value drops from the Alnus zone towards the dwarf shrub zone (not shown). For topological reasons the effect of Alnus was highest in plot 6 which was situated within the Alnus stands.

\section{Available nitrogen in soil}

To quantify differences in $\mathrm{N}$-concentration in the soil, nitrate as the plant-available nitrogen was determined in soil samples at sites b-1 to b-5. In the well-aerated alpine soil, only nitrate was detected as plant-available nitrogen. These data confirm that nitrate was washed-out from the Alnus site into the dwarf shrub zone (Fig. 4). As the soil was rich in particulate organic fragments and inhomogeneous, the nitrate content varied broadly within samples from the same plot. Differences between the Alnus site (b-1) and the Calamagrostis zone (b-2 and b-3) were statistically not significant $(\mathrm{n}=5$, significance level $5 \%$ ). The values of sites b- 1 and $b-2$ were statistically different from b- 4 and b-5 (= control); b-3, as well, was statistically different from b-5; see Additional file 2: Table S2.

\section{Photosynthetic activity measured by the prompt fluorescence}

The raw fluorescence kinetics of all plant species at all sites exhibited the typical polyphasic OJIP fluorescence rise. Raw data (Fig. 5a) often showed large differences in the fluorescence intensity. This was due to the variability between the various plants of the same species at different sites as well as within their leaves. While the mean value of the $F_{o}$ stayed at about the same level (see also Tables 2,3), the highest $F_{m}$ in single runs was up to 


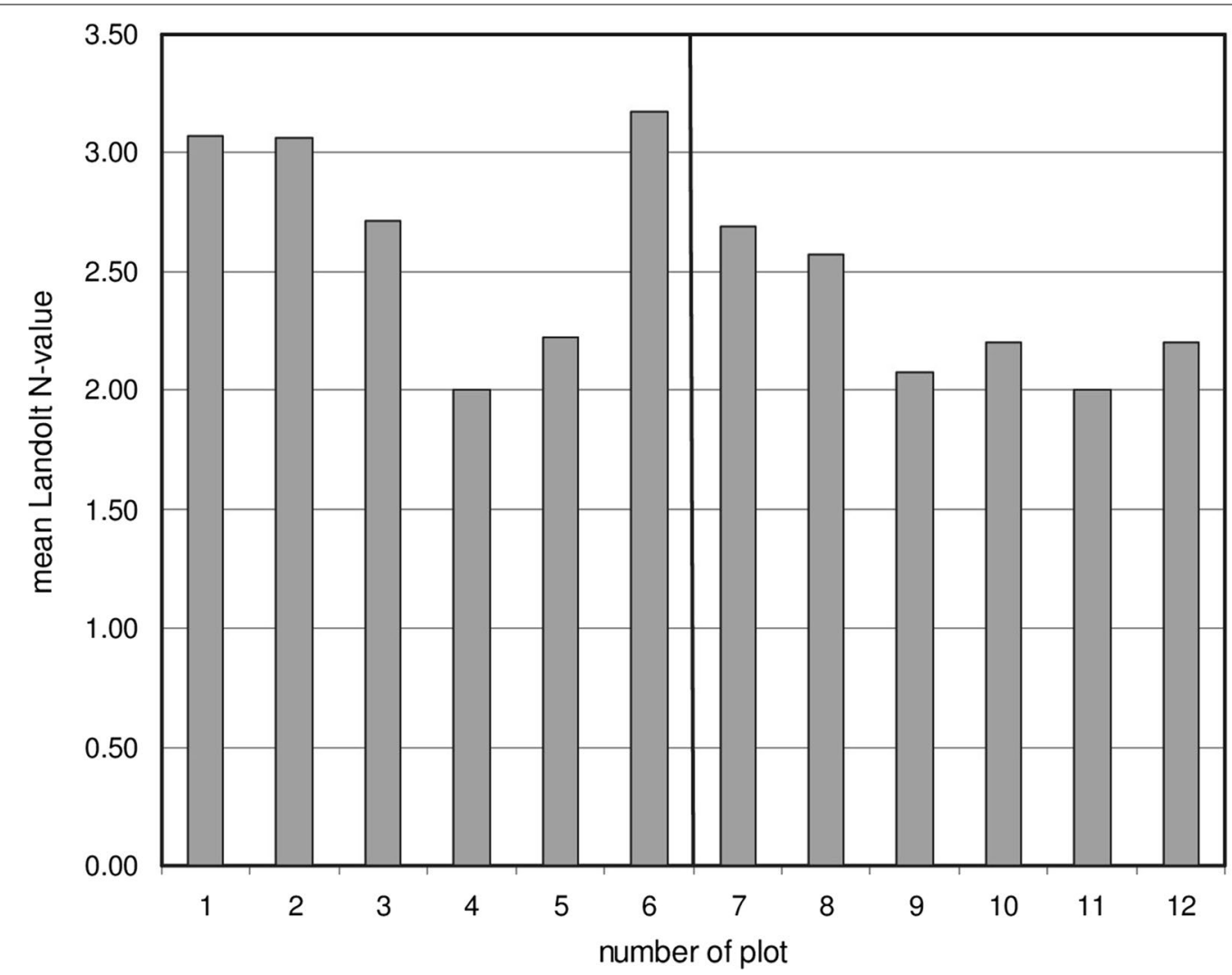

Fig. 3 Mean of indicator values calculated from plant frequency [1] and Landolt indicator value [17] for the 12 sampling plots in the horizontal (1-6) and the vertical (7-12) transects (see Fig. 2)

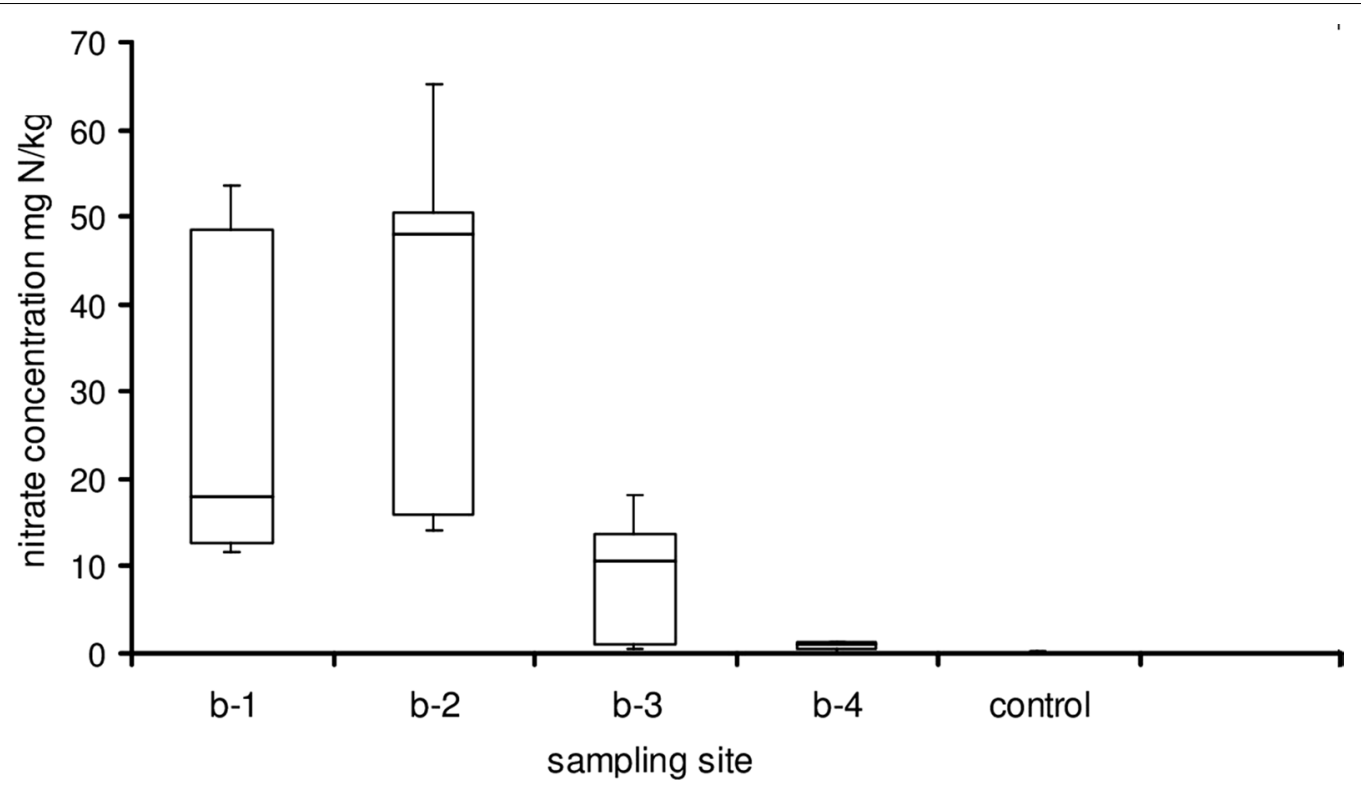

Fig. 4 Nitrate concentration in soil (mg nitrate-N/kg dry soil, for the sampling sites see Fig. 2). Box plot with median value, 25th and 75th percentiles and minimum and maximum values ( $n=5$, control = sampling site b-5). For statistical treatment see text and Additional file 2 : Table $\mathbf{2} 2$ 


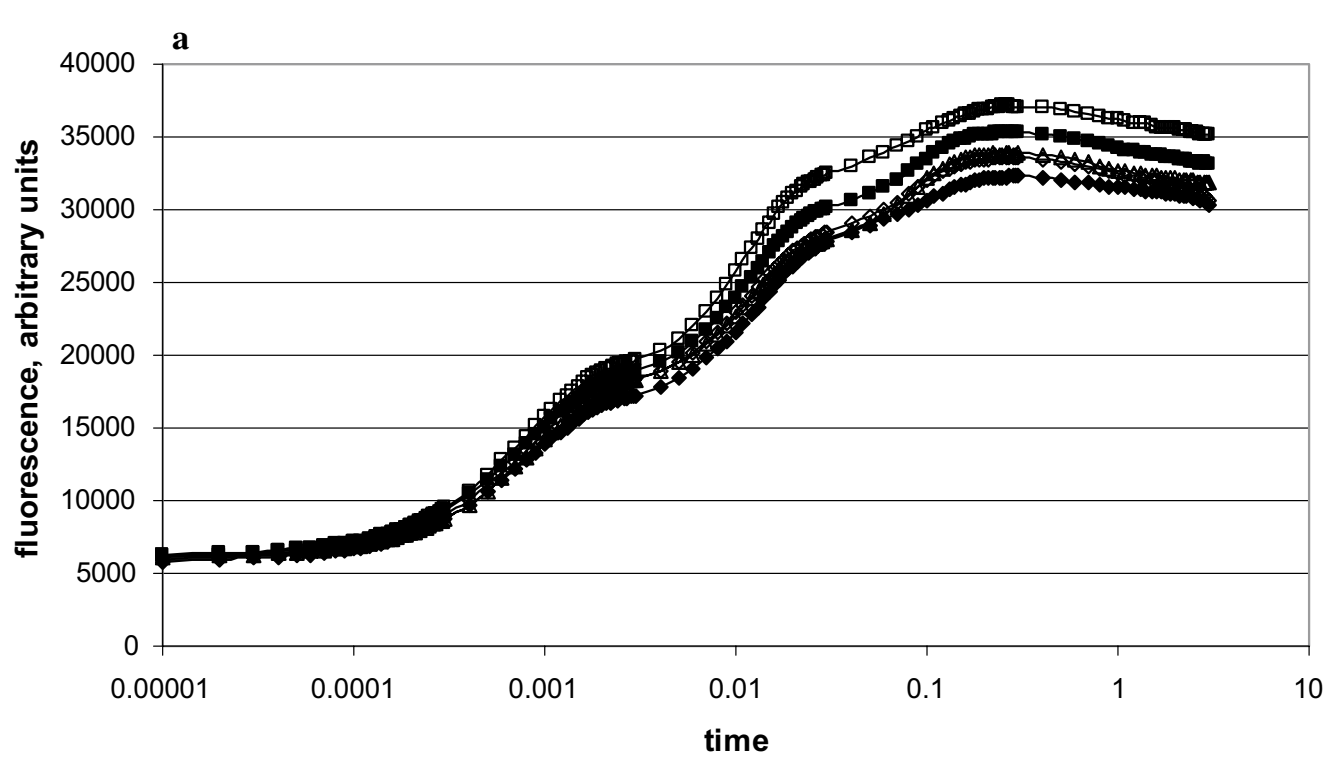

b

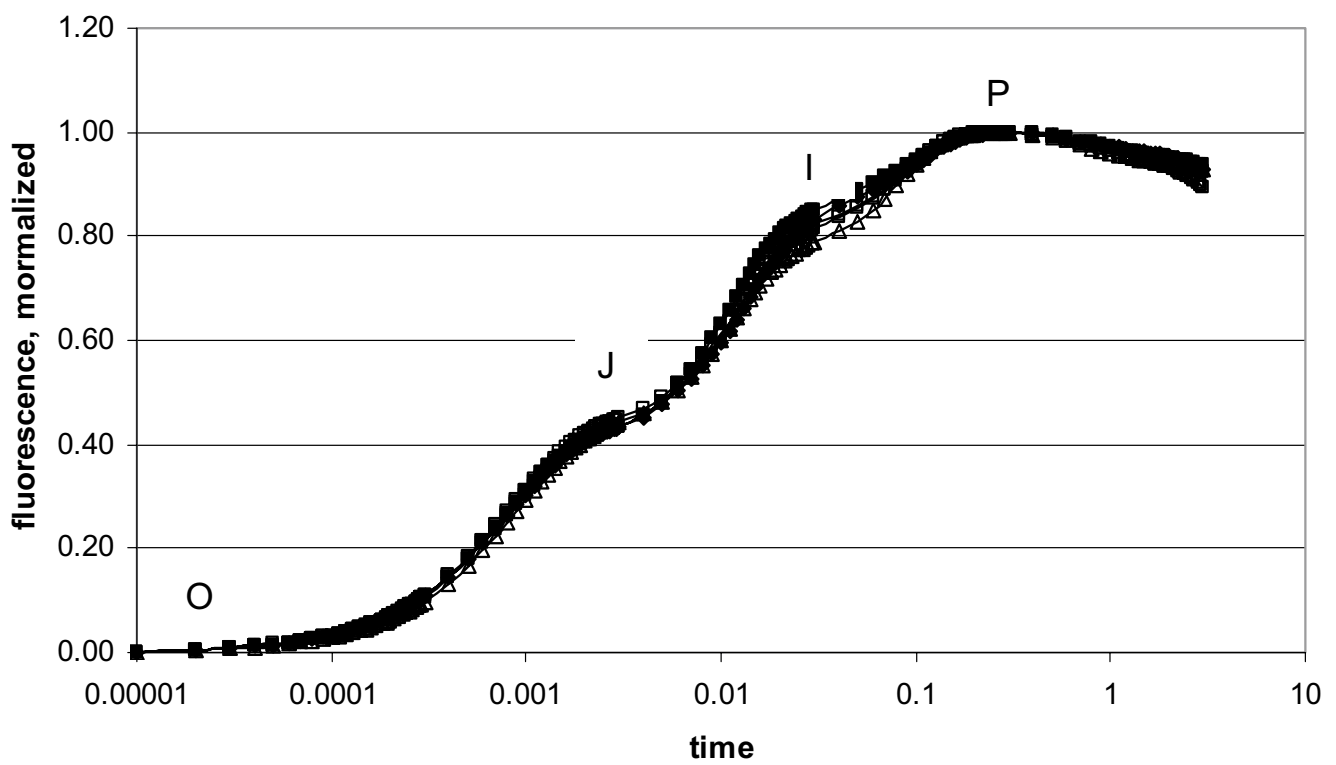

Fig. 5 Fluorescence induction scans from $10 \mu$ s to 3 s of 5 different Alnus leaves from site b-1, a raw data, $\mathbf{b}$ the same data after double normalization between $F_{0}=0$ and $F_{\max }$ at $0.3 \mathrm{~s}=1$. All data points are means of 15 measurements (data of 2. August 2017)

twice that of the lowest one in plants in the heterogeneous shrub zone, due to leaf age and local soil conditions. For further analysis, $\mathrm{F}_{\mathrm{o}}$ and $\mathrm{F}_{\mathrm{m}}$ data were double normalized between the time $10 \mu \mathrm{s}$ for $\mathrm{F}_{\mathrm{o}}=0$ and $0.3 \mathrm{~s}$ for $\mathrm{F}_{\mathrm{m}}=1$ (Fig. 5b). This allowed searching for individual differences within the induction phase. By averaging the data of 15 measurements for the same plant species and location, specific environmental effects in photosynthetic performance at different sites became in evidence. The data of the three selected plants, Calamagrostis, Rhododendron and Vaccinium, demonstrated kinetic differences relative to the nitrate concentration in the soil. In summary all tested plant species displayed a more rapid fluorescence rise at lower nitrate, indicating a faster closure of the primary acceptor of PSII and a reduced electron flow beyond. In Vaccinium the differences between lower and higher nitrate availability were small and only visible in the JI part of the fluorescence rise. In Rhododendron the two traces had already separated by $0.2 \mathrm{~ms}$, while in Calamagrostis they splitted only after $3 \mathrm{~ms}$ (Fig. 6). 
Table 2 Selected parameters from OJIP prompt fluorescence rise (data of 2. August 2017) for the species Alnus, Calamagrostis and Rhododendron

\begin{tabular}{|c|c|c|c|c|c|}
\hline plants & Alnus & \multicolumn{2}{|c|}{ Calamagrostis } & \multicolumn{2}{|c|}{ Rhododendron } \\
\hline \begin{tabular}{|l|} 
Vegetation \\
zone \\
\end{tabular} & Alnus & $\begin{array}{c}\text { Calamagrostis } \\
\text { near Alnus } \\
\end{array}$ & $\begin{array}{c}\text { Calamagrostis } \\
\text { near shrub zone }\end{array}$ & $\begin{array}{c}\text { Calamagrostis } \\
\text { near Alnus }\end{array}$ & $\begin{array}{l}\text { shrub } \\
\text { zone }\end{array}$ \\
\hline sampling site & b-1 & $\mathrm{b}-2$ & $b-3$ & $\mathrm{~b}-2$ & $\mathrm{~b}-4$ \\
\hline $\begin{array}{l}\text { Fv/Fm } \\
\text { mean } \\
\text { s.d. } \\
\end{array}$ & $\begin{array}{l}\mathbf{0 . 8 3} \\
0.01 \\
\end{array}$ & $\begin{array}{l}\mathbf{0 . 7 8} \\
0.04 \\
\end{array}$ & $\begin{array}{l}\mathbf{0 . 8 0} \\
0.06 \\
\end{array}$ & $\begin{array}{l}\mathbf{0 . 8 2} \\
0.02 \\
\end{array}$ & $\begin{array}{l}\mathbf{0 . 8 1} \\
0.03 \\
\end{array}$ \\
\hline $\begin{array}{l}\text { Fo } \\
\text { mean } \\
\text { s.d. } \\
\end{array}$ & $\begin{array}{c}\mathbf{5 5 9 7} \\
241 \\
\end{array}$ & $\begin{array}{l}6998 \\
1184 \\
\end{array}$ & $\begin{array}{c}7228 \\
508\end{array}$ & $\begin{array}{c}6299 \\
480 \\
\end{array}$ & $\begin{array}{l}\mathbf{6 5 9 2} \\
1364 \\
\end{array}$ \\
\hline \begin{tabular}{|l|} 
initial \\
velocity \\
$\mathrm{V}_{\text {init }}{ }^{\mathrm{a}}$ \\
mean \\
s.d. \\
\end{tabular} & $\begin{array}{l}\mathbf{0 . 2 9} \\
0.03 \\
\end{array}$ & $\begin{array}{l}\mathbf{0 . 6 3} \\
0.18 \\
\end{array}$ & $\begin{array}{l}\mathbf{0 . 6 3} \\
0.10 \\
\end{array}$ & $\begin{array}{l}\mathbf{0 . 2 6} \\
0.04 \\
\end{array}$ & $\begin{array}{l}\mathbf{0 . 4 1} \\
0.04 \\
\end{array}$ \\
\hline $\begin{array}{l}\text { J-value } \\
(3 \text { msec }) \\
\text { mean } \\
\text { s.d. }\end{array}$ & $\begin{array}{l}\mathbf{0 . 4 5} \\
0.05 \\
\end{array}$ & $\begin{array}{l}\mathbf{0 . 3 3} \\
0.08 \\
\end{array}$ & $\begin{array}{l}\mathbf{0 . 4 4} \\
0.03 \\
\end{array}$ & $\begin{array}{l}\mathbf{0 . 3 5} \\
0.03 \\
\end{array}$ & $\begin{array}{l}\mathbf{0 . 4 8} \\
0.03 \\
\end{array}$ \\
\hline $\begin{array}{l}\text { PI } \\
\text { mean } \\
\text { s.d. }\end{array}$ & $\begin{array}{l}6.19 \\
1.03 \\
\end{array}$ & $\begin{array}{l}\mathbf{2 . 9 8} \\
1.06 \\
\end{array}$ & $\begin{array}{l}\mathbf{2 . 6 3} \\
0.85\end{array}$ & $\begin{array}{l}8.67 \\
2.19 \\
\end{array}$ & $\begin{array}{l}\mathbf{3 . 4 8} \\
0.63\end{array}$ \\
\hline
\end{tabular}

For Calamagrostis and Rhododendron the data at the two sites in the nitrate gradient (b-2 with b-3 and b-2 with b-4, respectively) are compared. All numbers are means of 15 measurements. Colored squares identify the plants for which the results are statistically different $(p<0.01)$ at the two sites

${ }^{a}$ the initial velocity has been calculated as $V_{\text {init }}=F_{V 150 \mu s e c} / 0.15$

Several parameters can be extracted from prompt fluorescence; they give quantitative informations and can be treated with statistical tools.

Tables 2, 3 list some parameters which others have described as being affected by environmental impacts. They are compared pairwise for the same plant at different $\mathrm{N}$-contents in the soil.

The most frequently used parameter so far in the literature to quantify the photosynthetic performance is the $\mathrm{F}_{\mathrm{v}} /$ $\mathrm{F}_{\mathrm{m}}$ value, the maximum yield of primary photochemistry. In healthy plants it is around 0.8 , but many environmental effects may lower it substantially. The mean values of 15 measurements in such a diverse habitat type spanned the range for all plants and locations from 0.71 to 0.83 ; and these values were significantly lower mid-September as compared to beginning of August. In early August the $\mathrm{F}_{\mathrm{v}} / \mathrm{F}_{\mathrm{m}}$ values of Alnus, Calamagrostis and Rhododendron stayed high around 0.8; 6 weeks later all values had dropped. As in summer the highest values were observed in fall with Vaccinium and Avenella in or near the shrub zone. Regarding a nitrogen effect, only Calamagrostis, in fall, showed a higher $\mathrm{F}_{\mathrm{v}} / \mathrm{F}_{\mathrm{m}}$ value near the Alnus zone (b-2) as compared to the shrub zone (b-3). The difference is small, but statistically significant with $\mathrm{p}<0.01$. In contrast Rhododendron had slightly lower but not significant values near the Alnus zone (b-2) as compared to in the shrub zone (b-4). For Vaccinium no statistical difference was observed between the two sites and the value for Avenella was similar to Vaccinium.

The initial fluorescence, $\mathrm{F}_{\mathrm{o}}$, has also been suggested to respond to environmental signals: it rises at stress situations, e.g. after long drought periods [9]. The $\mathrm{F}_{\mathrm{o}}$ variation observed along the transect ranged mid September from 5314 counts for Alnus to 7228 in early August for Calamagrostis near the shrub zone. In early August there was no difference between the two sites, neither for Calamagrostis nor for Rhododendron. In contrast, in mid September the level of $F_{o}$ in both species was statistically different for the two sites $(\mathrm{p}<0.01)$, interestingly both species with a higher $\mathrm{F}_{\mathrm{o}}$ near the Alnus zone with more nitrogen. For Rhododendron the value near Alnus (b-2) was statistically different from the one sampled in the shrub zone (b-4); also the $\mathrm{F}_{\mathrm{o}}$ values for Vaccinium are different for the two sites ( $b-3$ and $b-4)(p<0.02)$.

As shown in Fig. 6, for both Calamagrostis and Rhododendron, the initial fluorescence rise was different between plants near the Alnus site as compared to those at some distant away. The initial slope $\mathrm{dF}_{\mathrm{v}} / \mathrm{dt}$ is a measure of the initial rate of the closure of the RC of PS II; it increases when the electron transport beyond the 
Table 3 Selected parameters from OJIP prompt fluorescence rise (data of 13. September 2017) for the species Alnus, Calamagrostis, Rhododendron, Vaccinium and Avenella

\begin{tabular}{|c|c|c|c|c|c|c|c|c|}
\hline plant & Alnus & Calama & grostis & Rhodode & dron & Vacciniu & & Avenella \\
\hline $\begin{array}{l}\text { Vegetation } \\
\text { zone }\end{array}$ & Alnus & $\begin{array}{c}\text { Calamag } \\
\text { rostis } \\
\text { near } \\
\text { Alnus }\end{array}$ & $\begin{array}{c}\text { Calamag } \\
\text { rostis } \\
\text { near } \\
\text { shrub } \\
\text { zone }\end{array}$ & $\begin{array}{c}\text { Calamag } \\
\text { rostis } \\
\text { near } \\
\text { Alnus }\end{array}$ & $\begin{array}{l}\text { in shrub } \\
\text { zone }\end{array}$ & $\begin{array}{c}\text { Calamag } \\
\text { rostis } \\
\text { near } \\
\text { shrub } \\
\text { zone }\end{array}$ & $\begin{array}{l}\text { in shrub } \\
\text { zone }\end{array}$ & $\begin{array}{c}\text { in shrub } \\
\text { zone }\end{array}$ \\
\hline $\begin{array}{l}\text { sampling } \\
\text { site }\end{array}$ & b-1 & b-2 & b-3 & b-2 & b-4 & b-3 & b-4 & b-4 \\
\hline $\begin{array}{l}\mathrm{Fv} / \mathrm{Fm} \\
\text { mean } \\
\text { s.d. }\end{array}$ & $\begin{array}{c}\mathbf{0 . 7 2} \\
0.057\end{array}$ & $\begin{array}{c}\mathbf{0 . 7 6} \\
0.040\end{array}$ & $\begin{array}{c}\mathbf{0 . 7 1} \\
0.027\end{array}$ & $\begin{array}{c}\mathbf{0 . 7 3} \\
0.099\end{array}$ & $\begin{array}{c}\mathbf{0 . 7 5} \\
0.036\end{array}$ & $\begin{array}{l}\mathbf{0 . 8 0} \\
0.031\end{array}$ & $\begin{array}{c}\mathbf{0 . 8 0} \\
0.017\end{array}$ & $\begin{array}{c}\mathbf{0 . 8 1} \\
0.012\end{array}$ \\
\hline $\begin{array}{l}\text { Fo } \\
\text { mean } \\
\text { s.d. }\end{array}$ & $\begin{array}{c}\mathbf{5 3 1 4} \\
603\end{array}$ & $\begin{array}{l}\mathbf{6 8 2 9} \\
656\end{array}$ & $\begin{array}{c}\mathbf{6 2 5 7} \\
447\end{array}$ & $\begin{array}{l}7105 \\
1205\end{array}$ & $\begin{array}{c}6251 \\
553\end{array}$ & $\begin{array}{c}6177 \\
403\end{array}$ & $\begin{array}{c}\mathbf{5 6 8 1} \\
628\end{array}$ & $\begin{array}{l}6272 \\
1178\end{array}$ \\
\hline $\begin{array}{l}\text { initial } \\
\text { velocity } \\
\text { Vinit }^{\mathrm{a}} \\
\text { mean } \\
\text { s.d. }\end{array}$ & $\begin{array}{l}\mathbf{0 . 4 2} \\
0.08\end{array}$ & $\begin{array}{l}\mathbf{0 . 5 7} \\
0.12\end{array}$ & $\begin{array}{l}\mathbf{0 . 8 1} \\
0.11\end{array}$ & $\begin{array}{l}\mathbf{0 . 3 9} \\
0.12\end{array}$ & $\begin{array}{l}\mathbf{0 . 3 1} \\
0.07\end{array}$ & $\begin{array}{l}\mathbf{0 . 3 6} \\
0.06\end{array}$ & $\begin{array}{c}\mathbf{0 . 3 6} \\
0.05\end{array}$ & $\begin{array}{l}0.49 \\
0.06\end{array}$ \\
\hline $\begin{array}{l}\text { J-value } \\
(3 \mathrm{msec}) \\
\text { mean } \\
\text { s.d. }\end{array}$ & $\begin{array}{c}\mathbf{0 . 5 5} \\
0.05 \\
\end{array}$ & $\begin{array}{l}\mathbf{0 . 5 1} \\
0.06 \\
\end{array}$ & $\begin{array}{c}\mathbf{0 . 5 7} \\
0.04 \\
\end{array}$ & $\begin{array}{l}\mathbf{0 . 5 3} \\
0.06 \\
\end{array}$ & $\begin{array}{l}\mathbf{0 . 4 1} \\
0.05 \\
\end{array}$ & $\begin{array}{l}\mathbf{0 . 4 4} \\
0.05\end{array}$ & $\begin{array}{l}\mathbf{0 . 4 9} \\
0.05\end{array}$ & $\begin{array}{l}0.46 \\
0.03\end{array}$ \\
\hline $\begin{array}{l}\text { PI } \\
\text { mean } \\
\text { s.d. }\end{array}$ & $\begin{array}{l}2.16 \\
1.10\end{array}$ & $\begin{array}{c}\mathbf{1 . 9 6} \\
0.96\end{array}$ & $\begin{array}{l}\mathbf{0 . 8 7} \\
0.29\end{array}$ & $\begin{array}{l}2.56 \\
1.54\end{array}$ & $\begin{array}{l}4.12 \\
1.65\end{array}$ & $\begin{array}{l}4.56 \\
1.26\end{array}$ & $\begin{array}{l}3.85 \\
1.48\end{array}$ & $\begin{array}{l}3.10 \\
0.63\end{array}$ \\
\hline
\end{tabular}

For Calamagrostis, Rhododendron and Vaccinium the data at the two sites in the nitrate gradient (b-2 with b-3, b-2 with b-4 and b-3 with b-4, respectively) are compared. All numbers are means of 15 measurements. Colored squares identify the plants for which the results are statistically different ( $p<0.01$ ) at the two sites

${ }^{a}$ the initial velocity has been calculated as $V_{\text {init }}=F_{V 150 \mu s e c} / 0.15$

primary acceptor of PS II is impeded. In summer no difference was seen for Calamagrostis, while Rhododendron reacted to limiting nitrogen by a more rapid initial increase. In September, with all species, the initial rise was faster compared to beginning of August; while in summer Calamagrostis had identical values for $\mathrm{V}_{\text {init }}$, it was in fall about $30 \%$ higher at the site near the shrub zone (b-3) compared to near Alnus (b-2). In Rhododendron $\mathrm{V}_{\text {init }}$ differed in summer with lower values at the site near Alnus (b-2). In contrast the situation was reversed mid September when the shrub zone (b-4) had a lower $\mathrm{V}_{\text {init }}$.

The J value, the normalized relative fluorescence level reached after $3 \mathrm{~ms}$, is as well a measure of how fast the primary acceptor of PSII becomes reduced. Calamagrostis and Rhododendron presented both in summer and fall a better photosynthetic performance close to the Alnus zone with its higher nitrogen content in the soil. In contrast, in September the J-value of Rhododendron close to Alnus was clearly higher. The J-values of Vaccinium gave a better performance in Calamagrostis (b-3) compared to the site in the shrub zone (b-4).
The photosynthetic index PI is a parameter frequently used for measuring environmental stress effects, especially for monitoring the vitality of crop plants. Similar to the other parameters described above, the PI of Calamagrostis had dropped in fall. In summer the difference between higher and lower nitrate content (b-2 compared to b-3) was small but significant; the difference was double that of September $(\mathrm{p}<0.001)$. In summer Rhododendron had quite higher values near Alnus (b-2) with a $\mathrm{p}<0.001$ compared to the site in the shrubs (b-4). For Vaccinium the two sites were statistically identical.

Various stress situations cause specific differences in the early fluorescence rise at around $300 \mu \mathrm{s}$, the $\mathrm{K}$ band. In our experiments, as shown in Fig. 7, when the differences (within the first $3 \mathrm{~ms}$ ) between the three species, Calamagrostis, Rhododendron and Vaccinium, close to and away from Alnus, are compared, clear differences are apparent: In Calamagrostis the signal (higher N-lower $\mathrm{N}$ ) is positive, while in Rhododendron and Vaccinium it is negative with a delayed minimum at $1 \mathrm{~ms}$.

The final section of induction kinetic, the I-P part, gives some information on the electron transport from PS 

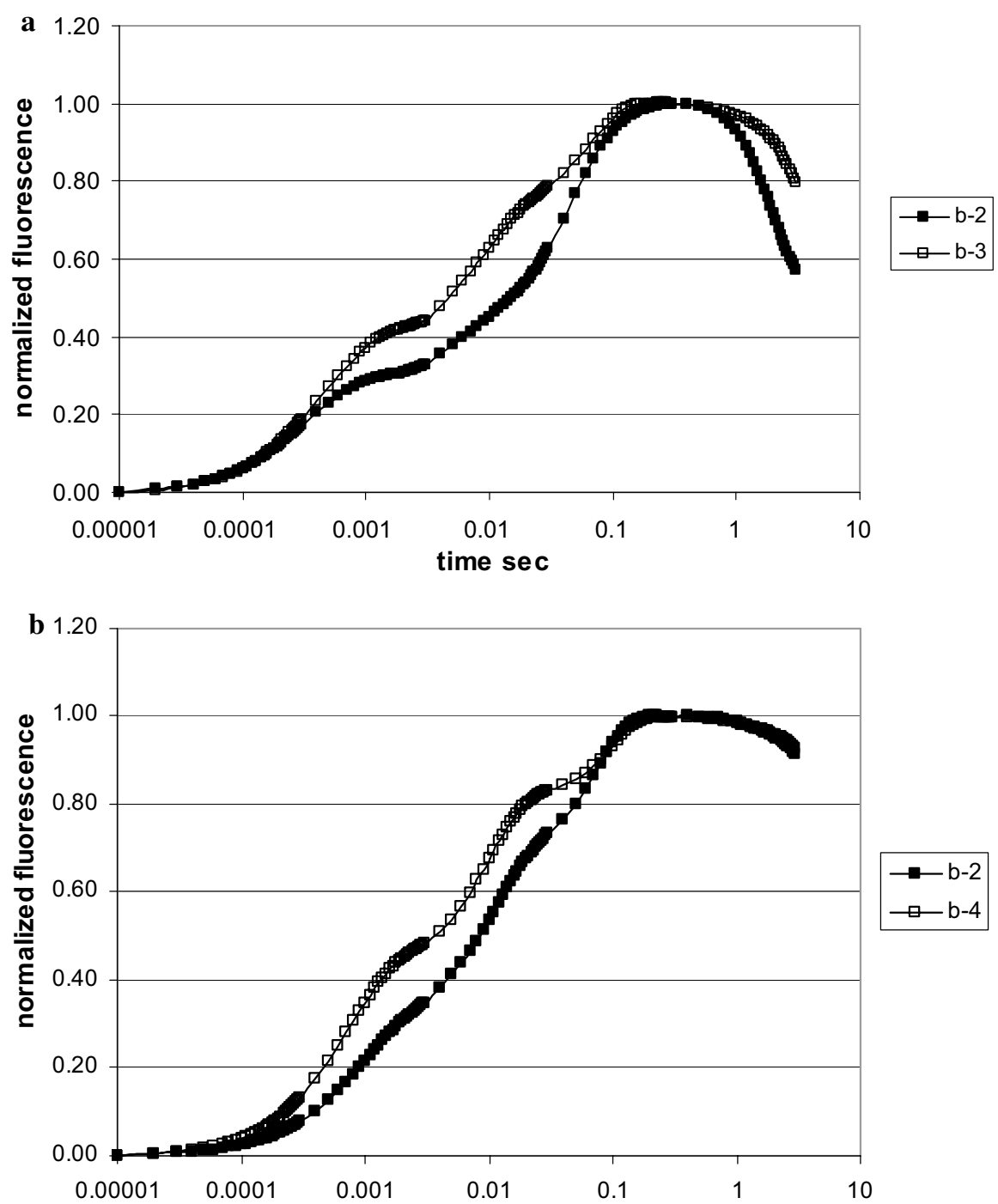

time sec

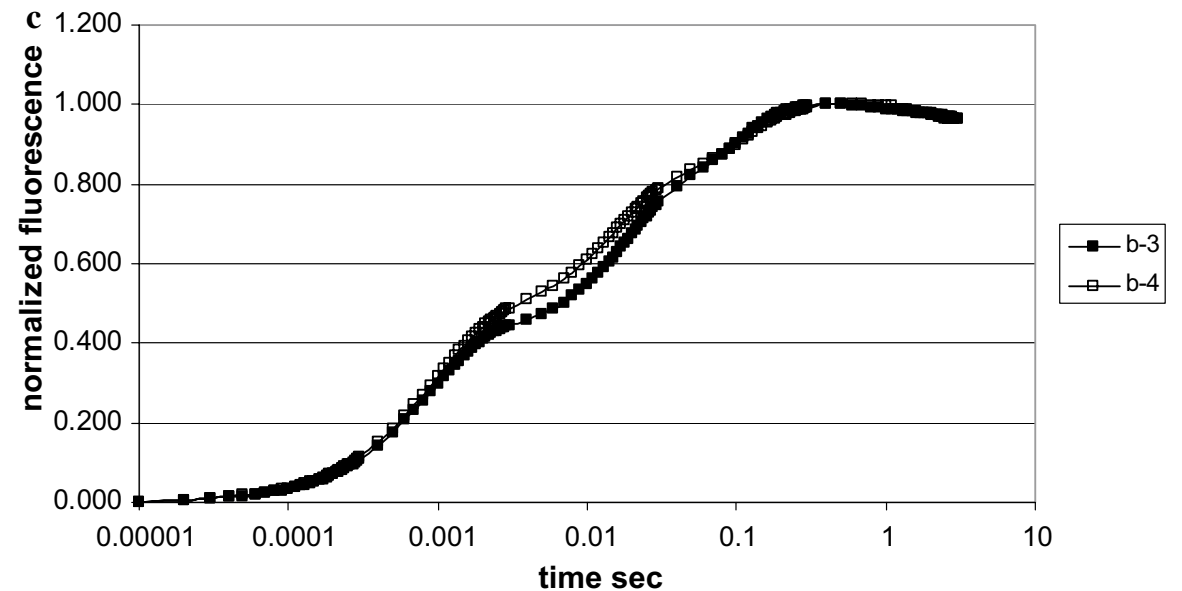

Fig. 6 Fluorescence induction scans from $10 \mu \mathrm{s}$ to $3 \mathrm{~s}$ after double normalization between $F_{0}=0$ and $F_{\max }$ at $0.3 \mathrm{~s}=1$, for Calamagrostis (sites $b-2$ and b-3), Rhododendron (sites b-2 and b-4) (data of 2. August 2017) and Vaccinium (sites b-3 and b-4) (data of 13. September 2017). All data points are means of 15 measurements 


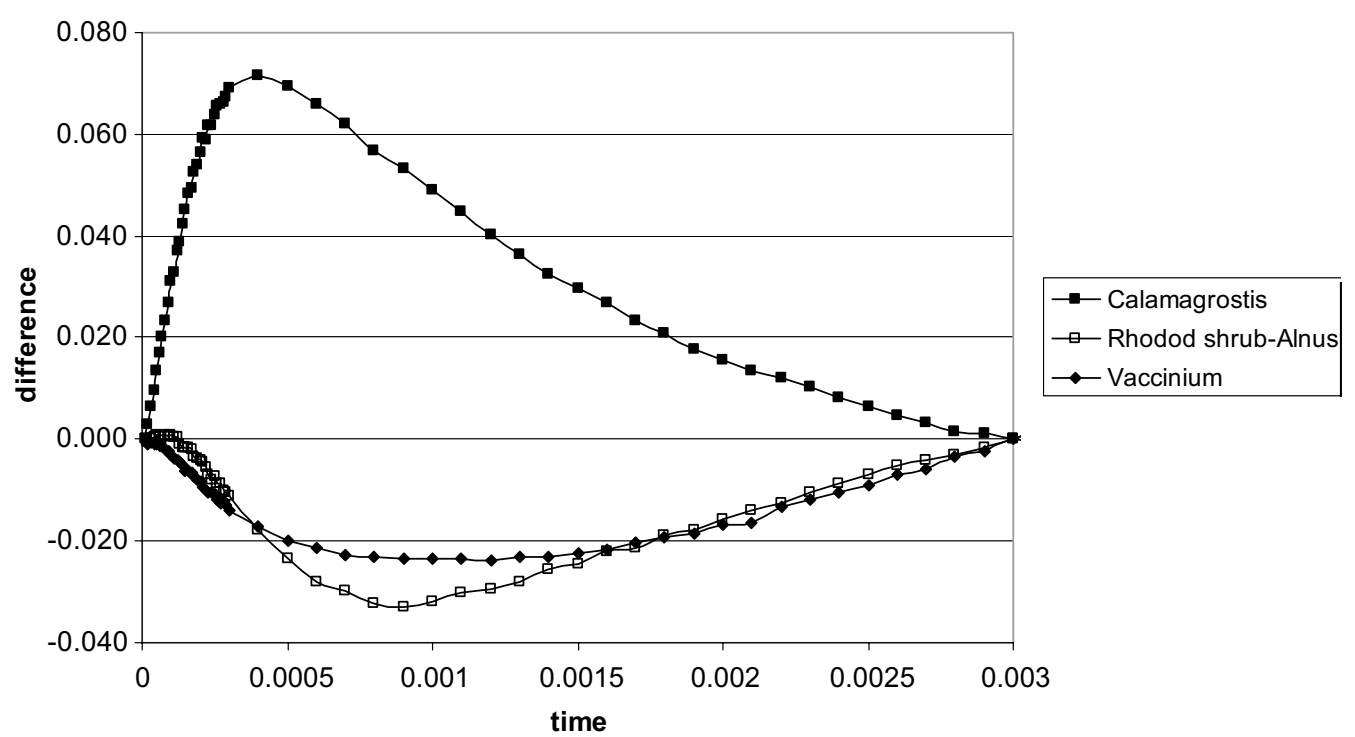

Fig. 7 Differences in the fluorescence kinetics between sites of low and high nitrogen for Calamagrostis (sites b-3 versus b-2), Rhododendron (sites b-4 versus b-2) and Vaccinium (sites b-4 versus b-3) after double normalization between time 0 and 3 ms with linear time scale (K-band) (data of 13. September 2017)

II to PS I and beyond. For all three tested species, clear differences were observed (Fig. 8). After normalizing between 0 and $3 \mathrm{~ms}(\mathrm{O}-\mathrm{J}$ phase), no differences between the sites of varying $\mathrm{N}$-availability were apparent within this time period; the traces are superimposed. However, the fluorescence kinetics separated between about 10 and $100 \mathrm{~ms}$. All three plants had a higher electron transport activity at the site of higher nitrogen supply (b-2) as compared to the site near the shrub zone (b-3, b-4).

\section{Discussion}

Alnus viridis is widely present in the Swiss Alps at altitudes between 1500 and $2500 \mathrm{~m}$ a.s.l. and develops in many places when the alpine grass vegetation is not grazed by cattle or sheep. With its symbiotic partner Frankia alni, it affects the nitrogen supply in soil within and near the Alnus covered area, leading to a gradient of plant-available nitrogen away from Alnus stands. This has been confirmed by three observations: (a) analyses of nitrate in the soil (Fig. 4), (b) characterizing the plant diversity using the $\mathrm{N}$-index from the literature (Fig. 3), and (c) interpreting the responses of the plant photosynthetic performance with fast fluorescence kinetics (Figs. 6, 7, 8).

The dispersal of different species along the two transects (2. August 2017) indicate the allocation of differently adapted species to the nitrogen content of the soil (Table 1). Plant indicator values have been empirically worked out for each species by comparing growth and ability for competition in relation to available nitrogen in soil under natural conditions $[7,16,17,32]$. When combined with the plant frequency in each plot, these values correlate well with the actual nitrate concentration (Fig. 3). High values were found for plot 1, 6 and 7, all situated within the area of Alnus plants, while the values of the plots in the shrub zone are clearly lower.

The plant community composition has a strong influence on the retention as well as on the loss of nutrients on a local as well as in a watershed scale. Nitrate and dissolved organic nitrogen concentrations in small rivers are strongly related to the vegetation cover in its watershed. In a region in Oregon (USA) dominated by red alder, a massive leaching of nitrogen was observed [6]. Similarly, in our experiment Alnus viridis acts as a strong control on ecosystem function and plant diversity.

Effects of nitrogen supply on photosystem II photochemistry have been studied for various important crop plants [12, 13, 18, 19, 25, 33, 37] Nitrogen deficiency, as a physical environmental stress factor, acted on the fluorescence induction rise during the first second. These lab experiments were run with plants under controlled growth conditions and with a defined addition of the nutrient. Observed effects can be compared to a control situation and correlated to the stress imposed. In field experiments real controls are missing, in our experiments we compared plants of the same species pairwise at different sites in a gradient of nitrate in the soil.

The most frequently used parameter to measure stress effects or the photosynthetic performance of plants is the maximum quantum yield of PS II, the ratio of the 

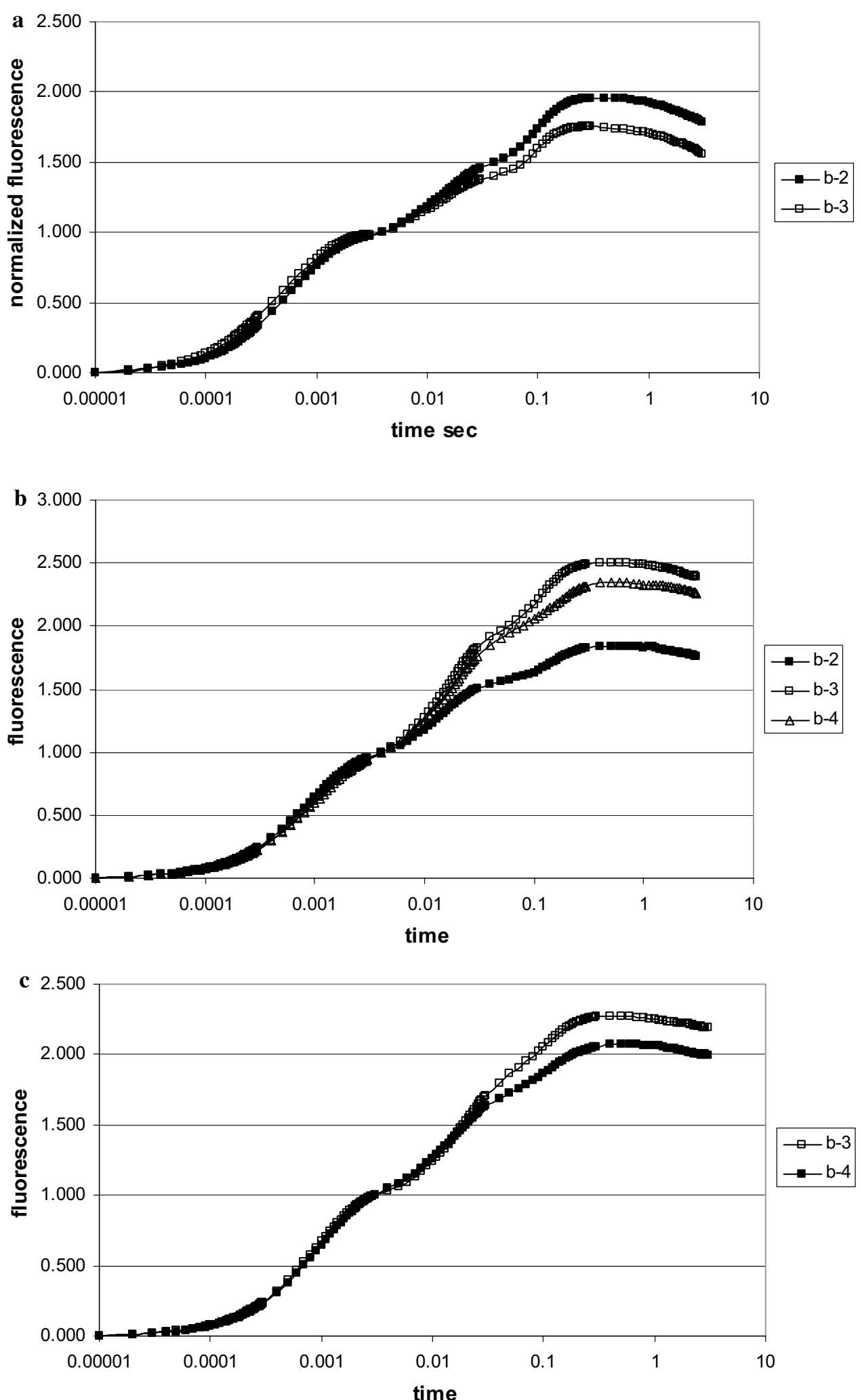

Fig. 8 Fluorescence induction scans from $10 \mu \mathrm{s}$ to $3 \mathrm{~s}$ after double normalization of the O-J phase between $F_{0}=0$ and $F_{J}$ at 3 ms $=1$. Calamagrostis (sites b-2 and b-3), Rhododendron (sites b-2 and b-4) (data of 2. August 2017) and Vaccinium (sites b-3 and b-4) (data of 13.September 2017). All data points are means of 15 measurements (for comparison see also Fig. 6) 
variable fluorescence to the maximum one $\left(\mathrm{F}_{\mathrm{v}} / \mathrm{F}_{\mathrm{m}}\right)$. However, compared with other indicators of photosynthetic performance, it has been found to not be very sensitive; no seasonal variation or response to drought was observed with beech saplings [22] or Triticum reacting only after long periods of dehydration [36].

Under nitrogen limitation the $\mathrm{F}_{\mathrm{v}} / \mathrm{F}_{\mathrm{m}}$ dropped in maize from 0.76 in the control to 0.68 , while in tomato the effect was even smaller [11]. Li et al. [18] reported only minimal differences for maize at 2 different levels of nitrogen in soil. Similarly, while water logging for 20 days reduced leaf nitrogen in Medicago sativa to less than half, at the same time the $\mathrm{F}_{\mathrm{v}} / \mathrm{F}_{\mathrm{m}}$ value dropped by about $15 \%$ [27].

In our experiments the relative deviation to the mean values of the $F_{v} / F_{m}$ with 15 measurements for each plant and each site was between 1.2 and $13.5 \%$, indicating some diversity between single plants within the same species and site. Tables 2, 3 present all data as mean values of 15 measurements. For all selected parameters white squares with the same species at the two sites of different soil nitrogen are statistically similar while colored fields are pairwise statistically different $(\mathrm{t}$-test $\mathrm{p}<0.01)$. Overall the $F_{v} / F_{m}$ values do not differ much in relation to the nitrate concentration, but they are clearly lower midSeptember compared to early August. In early August the values do not differ pairwise. However, 6 weeks later, the two values of Calamagrostis (b-2 and b-3) differ statistically $(\mathrm{p}<0.01)$. Similarly, in early August the two values of Rhododendron are identical, while in fall, the site near Alnus is statistically different from the site in the shrub zone. Vaccinium shows the highest $\mathrm{F}_{\mathrm{v}} / \mathrm{F}_{\mathrm{m}}$, but they are statistically identical. These data confirm that $F_{v} / F_{m}$ is only a rough measure of photosynthetic performance or vitality in a mixed plant population in an ecosystem of heterogenic soil and nutrient supply conditions.

The minimal fluorescence, $F_{0}$, is said to be sensitive towards environmental extremes $[5,9,13]$. Would $F_{o}$ also react on differences in nitrogen availability? In early August the differences in the level of $F_{o}$ are small and pair wise statistically not significant, while in mid-September, the $\mathrm{F}_{\mathrm{o}}$ of Calamagrostis at the two sites is different with a $\mathrm{p}<0.01$. For Rhododendron and Vaccinium statistical differences are found between the site near Alnus and the one more distant. However, in all cases the site of higher nitrate resulted in a higher level of $\mathrm{F}_{\mathrm{o}}$, which is in contrast to the expectation that stress will increase $F_{o}$. This shift in fluorescence intensity may be due to changes in fall in the optical properties of the different leaves induced by senescence, like changes in the pigment composition or the structure of the thylakoids.

The initial velocity of the fluorescence rise has not often been studied in plant stress experiments. The OJ phase reflects the speed of reduction of the primary acceptor
$\mathrm{Q}$, thus the more blocked QA is, the steeper is the initial fluorescence rise (Cicek et al. [5]. In early summer Calamagrostis showed a more rapid initial velocity, compared to Alnus and Rhododendron, with identical values for the two sites. In contrast Rhododendron showed a strong difference between the two sites, with better performance at lower nitrogen content. In fall the initial velocity in Calamagrostis at the two sites differed strongly, being $40 \%$ higher for the low nitrate site compared to close to the alder bushes. Rhododendron close to Alnus differs as well significantly from the other site. The performance of Vaccinium at the two sites is practically identical $(p=0.56)$. Again, the fall values for all species point to downgraded environmental conditions and plant senescence.

The level of the J-step is also a measure of stress, which is easily demonstrated in the kinetic data (Fig. 6). Nitrogen starvation also increased the J step [25], which has been discussed as a decrease in electron transport beyond the acceptor $\mathrm{Q}$. In our alpine nitrogen gradient both Calamagrostis and Rhododendron react significantly on nitrate differences in the soil both in early August and mid-September. It must be noted that for Calamagrostis the J-value in summer is the only parameter which is statistically different for the two sites of different $\mathrm{N}$-availability.

A positive K-band, located between the $\mathrm{O}$ and $\mathrm{J}$ step (Fig. 7), indicates a decrease of overall efficiency of activity of the oxygen evolving complex $[9,25,28]$. It is observed upon various stress situations. Under drought situations with barley the K-band changed from negative to positive, the stronger the stress acted upon the plants [21]. A positive K-band has also been observed in nitrogen fertilization experiments with crop plants after a lack of nutrients. Calamagrostis showed, both in early August (not shown) and mid-September, a strong positive difference between the two sites; interestingly the maximum was reached already after $300 \mu$ sec in September. In contrast, Rhododendron had a slightly positive signal in August which turned to a negative one in September. For Vaccinium the K-band was also negative. As nitrogen is a strong determinant of plant growth and up to $50 \%$ of leaf nitrogen is found in the photosynthetic structures, it is not astonishing that limited nitrogen supply for the densely growing Calamagrostis has severe effects on the sensitive oxygen-evolving system of the PSII with a high protein turnover. In the low nitrogen adapted shrubs Rhododendron and Vaccinium a strong K-band is missing.

The photosynthetic performance index PI has achieved an important measure of the overall vitality of the plant and contains information on the trapping of absorbed photons, on the activity of the reaction centers in 
photosystem II and the efficiency of the electron transport beyond PSII $[14,29,31]$. It is therefore highly sensitive to a multitude of environmental effects [13]. As a consequence, PI varies widely between different plant species, leaf age, season, the daily cycle and environmental effects, as well as for the same plant species between different sites [15, 23, 24, 36]. PI reacts also on various nutritional deficiencies including nitrogen [11]. As PI is positively correlated both with the nitrogen content of the leaves [20] and the rate of photosynthetic $\mathrm{CO}_{2}$-fixation [2], PI should be a good control for $\mathrm{N}$-deficiency $[11,18,25,29]$. It was therefore surprising, that PI for the 2 sites for Calamagrostis was statistically identical in early August, but changed to a strong difference midSeptember with a higher value at higher nitrogen. Higher nitrogen in soil resulted in a higher PI also in Rhododendron in early August. In contrast, in September the situation was reversed. In Vaccinium PI at the 2 sites was statistically identical, thus Vaccinium seems to be rather insensitive to a small $\mathrm{N}$-variation.

How do these alpine plants react upon varying nitrogen availability in soil? For Calamagrostis, the indicators extracted from the fluorescence data (except $F_{o}$ ) mid-September indicated positive differences for higher nitrogen between the sites near Alnus and the shrub bushes, demonstrating that the grass reacts positively to higher levels of nitrogen. In contrast in early August, although differences were visible in the averaged fluorescence scans (Fig. 6a), all parameters except for the variable fluorescence $F_{\mathrm{I}}$ at the J-step, indicated no differences between low and high nitrogen. Rhododendron was also influenced by the nitrogen content in soil. Beginning in August, it performed better near Alnus, while in September the situation became reversed. All parameters point to less photosynthetic efficiency near the Alnus site. During the summer growth period $\mathrm{N}$-availability was more important than mid September with already harsh climatic conditions above $2000 \mathrm{~m}$ a.s.l. Vaccinium seemed to be less sensitive towards changes in nitrogen; however, it must be noted that it was absent close to the Alnus front.

As many environmental factors affect parameters derived from fast fluorescence, one could question whether the described changes here are due specifically to the nitrate concentration in soil. However, as the distance between alder bushes and the dwarf shrub region is about $10 \mathrm{~m}$, different climatic effects are not plausible. Furthermore, the soil samples from the different sites (b-1 to b-5) are of similar structure, inhomogeneous and rich in coarse particulate dead plant organic matter. It is assumed that in this rather small habitat, the plants are well adapted to the present local prevailing environmental conditions and stay over the season in a slowly reacting dynamic equilibrium, including the nitrogen flow from the alder symbionts.

When the results of the two sampling dates are compared it is obvious that plant vitality is significantly better in summer. For Alnus PI dropped in fall by $65 \%$, a decline that holds also for $F_{v} / F_{m}$. The velocity of the initial rise and the position of the J-step increased. These indicators changed likewise in Calamagrostis and Rhododendron between early August and mid-September. Dropping temperatures and altered light conditions on the north-exposed hillside must have affected all plants, but certainly also had an impact on the nitrogen-fixation rate of the Alnus symbionts. This would then have altered the $\mathrm{N}$-gradient and thus the $\mathrm{N}$-supply for the grass and shrubs at the different sites. It must be noted that between the two sampling dates several strong drops in ambient temperature occurred as recorded in nearby meteorological stations (Swiss Meteo 2018).

\section{Conclusions}

The change in plant diversity in a small area away from Alnus bushes and trees suggested a strong dependency on the nitrogen supply in soil provided by the nitrogenfixing capacity of the root symbionts Frankia alni. This was confirmed by chemical nitrate analyses and strengthened by the distribution of the mean $\mathrm{N}$-indicator values of plots in the transects showing a gradient away from the Alnus-covered area. Prompt fluorescence OJIP measurements indicated that at lower nitrogen levels in the soil, the same plant species often showed signs of nutrient stress, such as more rapid reduction of the primary acceptor, a reduced capacity on the donor site of photosystem II and a lower performance index. This natural ecosystem was under quasi equilibrium conditions and slow changes in the seasonal cycle were taking place during this study. Fast fluorescence data showed differences in the photosynthetic metabolism within the same plant species when sites with high and low nitrogen soil concentration were compared. Not all species were equally sensitive. While the grass Calamagrostis reacted strongly to changes in soil nitrogen, Vaccinium was rather insensitive.

\section{Materials}

\section{Site description}

The experimental site is located in the Val Piora (Ticino, Switzerland) (N $46^{\circ} 32.671$ E $8^{\circ} 42.974,2040 \mathrm{~m}$ a.s.l.); the geographical location can be verified under//map. geo.admin.ch, using the search name "Alpe di Piora (TI)Quinto". A roughly rectangular N-E oriented area of about $30 \times 40 \mathrm{~m}$ in size with a slope of about $30^{\circ}-35^{\circ}$ is surrounded by Alnus viridis bushes and trees. A defined strip of grasses of 6 to $8 \mathrm{~m}$ width follows adjacent to 
the Alnus border (see Figs. 1, 2), consisting of mainly Calamagrostis varia. This strip then abruptly merges with dwarf shrubs dominated by Rhododendron ferrugineum and Vaccinium uliginosum. As soil structure and physical parameters are similar over the site, these distinct changes in plants composition may be based on the differences in nutrient content in the soil. A schematic drawing of the site is given in Fig. 2.

\section{Sampling, plant abundance}

The substratum consisted of $\sim 10-40 \mathrm{~cm}$ tall humus layer above Bündner shist (Penninicum). A horizontal and a vertical transect was selected within the area (Fig. 2) to characterize the species diversity. Each transect consisted of six plots or collection squares of $1 \times 1 \mathrm{~m}$ at every 4 to $5 \mathrm{~m}$. For every square the composition of species and their frequency were recorded on the 2nd of August 2017 following the cover abundance scale of Braun-Blanquet [1] (Table 1).

\section{Determining indicator values}

Landolt [16], Landolt et al. [17] and Ellenberg et al. [8] characterized many plant species empirically by a specific nitrogen $(\mathrm{N})$ indicator value. In this investigation we used the indicator values of Landolt et al. [17] which are based on a simple ordinal classification of plants according to the position of their realized ecological niche using the ordinal scale of 1 (=very low soil $\mathrm{N})$ to 10 (=very rich soil N). Thimonier et al. [32] used these indicators for monitoring the ground vegetation in forests. These index values for the plant species found are listed in column 1 of Additional file 1: Table S1. For all plant species present these indicator values for nitrogen were combined with the Braun-Blanquet frequencies of each species in each $1 \mathrm{~m}^{2}$ plot resulting in a mean indicator value for each plot. These values are shown for each plot in Fig. 3. The detailed calculation is given for plot 1 in Additional file 1 : Table S1.

\section{Nitrate determination in soil}

Using a spatula, five samples of soil of about $100 \mathrm{~g}$ were collected on the 13th September 2017 from the top $20 \mathrm{~cm}$ of each zone in the horizontal transect and from a control site distant from Alnus trees. Sampling sites are indicated in Fig. 2 (b-1, b-2, b-3, b-4). Sample b-5 was collected in the dwarf shrub vegetation about $100 \mathrm{~m}$ distance from Alnus vegetation.

For the nitrate determination, 5 separate aliquots of 15 to $50 \mathrm{~g}$ of fresh soil from each sample (b-1 to b-5) were manually homogenized and suspended in $100 \mathrm{ml} 0.01 \mathrm{M}$ $\mathrm{CaCl}_{2}$, stirred for $60 \mathrm{~min}$ at $\mathrm{RT}\left(25^{\circ} \mathrm{C}\right)$ on a lab shaker (Kühner) at $140 \mathrm{rpm}$, then filtrated through a Whatman 790 circular filter. The filtrate was directly used for the nitrate determination by a Skalar' Continuous Flow-Analyzer by measuring the absorbance at $540 \mathrm{~nm}$ according to the method designed by the Skalar company (Breda, The Netherlands). Nitrate was the only $\mathrm{N}$ species detected in the extracts. After extraction the dry weight of the samples was determined, and the nitrate concentration was calculated per dry weight of soil, taking the Flow-Analyzer volumes of each extract into account.

\section{Chlorophyll- $a$ fluorescence}

Chlorophyll- $a$ fluorescence was analyzed using the portable fluorometer Pocket PEA (Hansatech, King's Lynn, England) on the 2nd of August 2017 and the 13th September 2017 in the early afternoon. From the different plant samples found at the site, the following dominant species were selected: Alnus viridis, Rhododendron ferrugineum, Vaccinium uliginosum, Calamagrostis varia and Avenella flexuosa. Light-exposed, fully developped leaves were randomly selected from an area of $50 \times 50 \mathrm{~cm}$ (Calamagrostis, Avenella), respectively from several small shrubs (Rhododendron, Vaccinium) and from the outside of the larger bushes (Alnus). Plant material was sampled at the vegetation boundaries as determined for nitrate determination (b-1, b-2, b-3, b-4). Detached leaves were fixed in commercial leaf clips (Hansatech, England) and kept in the dark for $20 \mathrm{~min}$ prior to the fluorescence measurement [10, 31].

At each site (b-1 to b-4) fast fluorescence was measured with 5 leaves from different plants of the same species located at the same site. These experiments were repeated 3 times within $30 \mathrm{~min}$, leading to 15 measurements per plant and site.

Excitation intensity was $3500 \mu \mathrm{mol}$ photons $\mathrm{m}^{-2} \mathrm{~s}^{-1}$ with red light of $650 \mathrm{~nm}$ for $3 \mathrm{~s}$. From the fluorescence induction signal with high temporal resolution from $10 \mu \mathrm{s}$ to $3 \mathrm{~s}$, the instrument determined initial $\left(\mathrm{F}_{\mathrm{o}}\right)$ and maximum $\left(\mathrm{F}_{\mathrm{m}}\right)$ fluorescence and calculated the variable fluorescence $\left(\mathrm{F}_{\mathrm{v}}\right)$ at specified time intervals, and also provided further specific parameters such as the potential quantum yield of PS II $\left(\mathrm{F}_{\mathrm{v}} / \mathrm{F}_{\mathrm{m}}\right)$, or the performance index $\left(\mathrm{PI}_{\mathrm{ABS}}\right)$. For further calculations and the visualization, the experimental data were transferred into Excel sheets to calculate the mean value of all data points of each time course from 15 replicates of the same plant species and location. To reduce the variability due to e.g. leaf age and leaf position and local soil differences, the fluorescence induction curves were normalized by setting $\mathrm{F}_{\mathrm{o}}=0$ and $\mathrm{F}_{\mathrm{m}}=1$. The result is illustrated in Fig. 5 . The initial velocity was calculated as $\left(\mathrm{F}_{0.15 \mathrm{~ms}}-\mathrm{F}_{0}\right) / 0.15$.

\section{Statistical treatment}

To calculate mean values, standard deviation and significance with $\mathrm{t}$-test analysis the software MaxStat was 
used. All data points presented in the figures are means of 5 consecutive measurements which were repeated 3 times $(\mathrm{n}=15)$ in intervals of $30 \mathrm{~min}$. Additional file 2: Table S2 reports the statistical data of the nitrate concentrations.

\section{Supplementary information}

Supplementary information accompanies this paper at https://doi. org/10.1186/s12898-020-00292-9.

Additional file 1: Table S1. Calculation of the mean N-value of each plot from the indicator values of Landolt et al. [17] and its frequency based on Braun-Blanquet [1]. For each plant (in this example of plot 1 (Table 1)) the Braun-Blanquet frequency was increased by 1 to obtain values from 1 to 5. This number was multiplied by the Landolt-indicator value. The mean $\mathrm{N}$-value per plot results in the sum of these products divided by the sum of the new frequency values. The calculation steps are given below.

Additional file 2: Table S2. Statistical proof of significance ( $p$-values after Mann-Whitney, MaxStat-Lite, 3.60), 5 measurements per site b-1 to b-5.

\section{Abbreviations}

OJIP: Fast fluorescence rise from $\mathrm{F}_{\mathrm{o}}$ to $\mathrm{F}_{\mathrm{m}} ; \mathrm{F}_{\mathrm{o}}$ : Initial fluorescence $\mathrm{O} ; \mathrm{F}_{\mathrm{m}}$ : Maximal fluorescence $P$ after $1 \mathrm{~s} ; F_{v}$ : Variable fluorescence, $=\left(F_{m}-F_{0}\right)$; PI: Photosynthetic performance index; J-step: Variable fluorescence at $2 \mathrm{~ms},=F_{j}$ RC: Reaction center; PS II: Photosystem II; PS I: Photosystem I; K-band: Selected part of OJIP between $\mathrm{O}$ and J steps; PEA fluorimeter: Photosynthetic efficiency analyzer.

\section{Acknowledgements}

We thank Reto Strasser for the use of the PEA fluorometer and many fruitful discussions, Ferdinand Schanz for support in the statistical treatment, Tom Chasteen for thoroughly editing the text, the unknown reviewer for valuable text improvements, and the Alpine Biological Center Piora (http://www.cadag no.ch) for the nice hospitality.

\section{Authors' contributions}

The project was designed by JS and RB and the experimental work was carried out by KB, KR, DZ, LS and $\mathrm{RH}$. The manuscript and the figures have been prepared by RB and JS. All authors read and approved the final manuscript.

\section{Funding}

The work was generously supported by the Hydrobiologie-Limnologie Stiftung für Gewässerforschung, Zürich, the Stiftung Dreiklang für ökologische Forschung und Bildung, Basel, the Zürcher Universitätsverein, ZUNIV, Zürich, the Department of Plant and Microbial Biology of the University of Zürich and the Stiftung Centro di Biologia Alpina Piora, Bellinzona.

\section{Availability of data and materials}

The PEA data files can be obtained from the corresponding author.

\section{Ethics approval and consent to participate}

No endangered plants involved, the Center for Alpine Biology, Piora, has a permission for environmental ecological experiments in the Piora valley.

\section{Consent of publication}

Not applicable.

\section{Competing interests}

The authors declare no conflict of interest.

\footnotetext{
Author details

${ }^{1}$ Faculty of Natural Sciences, University of "Hasan Prishtina", Prishtina, Kosovo.

${ }^{2}$ Faculty of Natural Sciences, University of Tirana, Tirana, Albania. ${ }^{3}$ Dept. of Evolutionary Biology and Environmental Studies, University of Zürich, Zürich, Switzerland. ${ }^{4}$ Dept. of Systematic and Evolutionary Botany, University of Zürich, Zürich, Switzerland. ${ }^{5}$ Dept. of Plant and Microbial Biology, University of Zürich, Zürich, Switzerland.
}

Received: 19 October 2019 Accepted: 11 April 2020

Published online: 20 April 2020

\section{References}

1. Braun-Blanquet J. Pflanzensoziologie, Grundzüge der Vegetationskunde. 3rd ed. Berlin: Springer-Verlag; 1964.

2. Bucher SF, Bernhardt-Römermann M, Römermann C. Chlorophyll fluorescence and gas exchange measurements in field research: an ecological study. Photosynthetica. 2018;56:1161-70. https://doi.org/10.1007/s1109 9-018-0809-5.

3. Bussotti F, Strasser R, Schaub M. Photosynthetic behavior of woody species under high ozone exposure probed with the JIP-test: a review. Environ Pollut. 2007;147:430-7. https://doi.org/10.1016/j.envpol.2006.08.036.

4. Butler WL, Kitajiama M. Fluorescence quenching in photosystem II of chloroplasts. Biochim Biophys Acta. 1975;376:116-25. https://doi. org/10.1016/0005-2728(75)90210-8

5. Cicek N, Oukarroum A, Strasser RJ, Schanker G. Salt stress effects on the photosynthetic electron transport chain in two chickenpea lines differing in their salt stress tolerance. Photosynth Res. 2018;136:291-301. https:// doi.org/10.1007/s11120-017-0463-y.

6. Compton JE, Church MR, Larned ST, Hogsett WE. Nitrogen export from forested watersheds in the Oregon coast range: the role of N2-fixing red alder. Ecosystems. 2003;6:773-85. https://doi.org/10.1007/s1002 1-002-0207-4.

7. Diekmann M. Species indicator values as an important tool in applied plant ecology-a review. Basic Appl Ecol. 2003;4:403-508. https://doi. org/10.1078/1439-1791-00185.

8. Ellenberg H, Weber HE, Düll R, Wirth V, Werner W, Paulissen D. Zeigerwerte von Pflanzen in Mitteleuropa. Scripta Geobotanica. 1992;18:9-166.

9. Falqueto AR, Junior RA, Gomes MTG, Martins JPR, Silva DM, Partelli FL. Effects of drought stress on chlorophyll a fluorescence in two rubber tree clones. Scientia Horticult. 2017;224:238-44. https://doi.org/10.1016/j. scienta.2017.06.019.

10. Hansatech Operations Manual, 2006.

11. Kalaji HM, Oukarroum A, Alexandrov V, Kouzmanova M, Brestic M, Zivcak $M$, Samborska IA, et al. Identification of nutrient deficiency in maize and tomato plants by in vivo chlorophyll a fluorescence measurements. Plant Physiol Biochem. 2014;81:16-25. https://doi.org/10.1016/j.plaph y.2014.03.029.

12. Kalaji HM, Schansker G, Ladle RJ, Goltsev V, Bosa K, Allakhverdiev SI, et al. Frequently asked questions about in vivo chlorophyll fluorescence: practical issues. Photosynth Res. 2014;122:121-58. https://doi.org/10.1007/ s11120-014-0024-6.

13. Kalaji HM, Jajoo A, Oukarroum A, Brestic M, Zivcak M, Samborska IA, et al. Chlorophyll a fluorescence as a tool to monitor physiological status of plants under stress conditions. Acta Physiol Plant. 2016;38:102. https:// doi.org/10.1007/s11738-016-2113-y.

14. Kalaji HM, Schansker G, Brestic M, Bussotti F, Calatayud A, Ferroni L, et al. Frequently asked questions about in vivo chlorophyll fluorescence, the sequel. Photosynth Res. 2017;132:13-66. https://doi.org/10.1007/s1112 0-016-0318-y.

15. Killi D, Haworth M. Diffusive and metabolic constraints to photosynthesis in Quinoa during drought and salt stress. Plants. 2017;6:49. https://doi. org/10.3390/plants6040049.

16. Landolt E. Ökologische Zeigerwerte zur Schweizer Flora. Veröffentlichungen des Geobotanischen Institutes der Eidgenössischen Technischen Hochschule, Stiftung Rübel, Zürich. 1977;64:1-208.

17. Landolt E, Bäumler B, Erhardt A, Hegg O, Klölzli F, Lämmler W, et al. Flora indicativa Ökologische Zeigerwerte und biologische Kennzeichen zur Flora der Schweiz und der Alpen. Bern: Haupt Verlag; 2010.

18. Li G, Zhang ZS, Gao HY, Liu P, Dong ST, Zhang JW, Zhao B. Effects of nitrogen on photosynthetic characteristics of leaves from two different stay-green corn (Zea mays L.) varieties at the grain-filling stage. Can J Plant Sci. 2012;92:671-80. https://doi.org/10.4141/CJPS2912-039.

19. Lu C, Zhang J, Zhang Q, Li L, Kuang T. Modification of photosystem II photochemistry in nitrogen deficient maize and wheat plants. J Plant Physiol. 2001;158:1423-30. https://doi.org/10.1078/0176-1617-00501. 
20. Nikiforou C, Manetas Y. Inherent nitrogen deficiency in Pistacia lentiscus preferentially affects photosystem I: a seasonal field study. Funct Plant Biol. 2011;38:848-53. https://doi.org/10.1071/FP11040.

21. Oukarroum A, El Madidi S, Schansker G, Strasser RJ. Probing the responses of barley cultivars (Hordeum vulgare L.) by chlorophyll a fluorescence OLKJIP under drought stress and re-watering. Enviro Experim Botany. 2007;60:438-46. https://doi.org/10.1016/j.envexpbot.2007.01.002.

22. Pflug EE, Buchmann N, Siegwolf RT, Schaub M, Rigling A, Arend M. Resilient leaf physiological response of European beech (Fagus sylvatica L.) to summer drought and drought release. Front Plant Sci. 2018;9:187. https:// doi.org/10.3389/fpls.2018.00187.

23. Pollastrini M, Holland V, Brüggemann W, Bruelheide H, Danila I, Jaroszewicz B, Valladares F, Bussotti F. Taxonomic and ecological relevance of the chlorophyll a fluorescence signature of tree species in mixed European forests. New Phytol. 2016;212:51-65. https://doi.org/10.1111/nph.14026.

24. Pollastrini M, Nogales AG, Benavides R, Bonal D, Finer L, Fotelli M, Gessler A, Grossiord C, Radoglou K, Strasser RJ, Bussotti F. Tree diversity affects chlorophyll a fluorescence and other leaf traits of tree species in a boreal forest. Tree Physiol. 2017;37:199-208. https://doi.org/10.1093/treephys/ tpw132.

25. Redillas MCFR, Jeong JS, Strasser RJ, Kim YS, Kim JK. JIP analysis on rice (Oryza sativa cv Nipponbare) grown under limited nitrogen conditions. J. Korean Soc Appl Biol Chem. 2011;54:827-32. https://doi.org/10.3839/ jksabe-2011.127.

26. Schleppi P, Curtaz F, Kraause K. Nitrate leaching from sub-alpine coniferous forest subjected to experimentally increased $\mathrm{N}$ deposition for 20 years, and effects of tree gridling and felling. Biogeochemistry. 2017;134:319-35. https://doi.org/10.1007/s10533-017-0364-3.

27. Smethurst CF, Garnett T, Shabala S. Nutritional and chlorophyll fluorescence responses of lucerne (Medicago sativa) to water logging and subsequent recovery. Plant Soil. 2005;270:31-45. https://doi.org/10.1007/ s11104-004-1082.x.

28. Srivastava A, Guissé B, Greppin H, Strasser RJ. Regulation of antenna structure and electron transport in photosystem II of Pisum sativum under elevated temperature probed by the fast polyphasic chlorophyll a fluorescence transient: OKJIP. Biochem Biophys Acta. 1997;1320:95-109. https://doi.org/10.1016/S0005-2728(97)00017-0.

29. Stirbet A, Lazar D, Kromdijk J, Govindjee. Chlorophyll a fluorescence induction: can just a one-second measurement be used to quantify abiotic stress responses. Photosynthetica. 2018;56:86-104. https://doi. org/10.1007/s11099-018-0770-3.
30. Strasser BJ, Strasser RJ. Measuring fast fluorescence transients to address environmental questions: the JIP-test. In: Montpellier Mathis P. Photosynthesis: From light to biosphere. Proceedings of the 10th International Photosynthesis Congress. Dordrecht: Kluwer Academic Publishers; 1995. p. 977-980.

31. RJ Strasser, A Srivastava, M Tsimili-Michael. Analysis of the chlorophyll a fluorescence transient. In: Papageorgiu GC, Govindjee (eds.) Chlorophyll a fluorescence. A signature of photosynthesis. Advances in Photosynthesis and Respiration, 19. Dordrecht: Springer; 2004. p. 321-362

32. Thimonier A, Kull P, Keller W, Moser B, Wohlgemuth T. Ground vegetation monitoring in Swiss forests: comparison of survey methods and implications for trend assessments. Environ Monit Assessm. 2011;174:47-63.

33. Tsimilli-Michael M, Eggenberg B, Biro B, Köves-Pechy K, Vörös I, Strasser RJ. Synergistic and antagonistic effects of arbuscular mycorrhizal fungi and Azospirillum and Rhizobium nitrogen-fixers on the photosynthetic activity of alfalfa, probed by the polyphasic chlorophyll a fluorescence transient O-J-I-P. Appl Soil Ecol. 2000;15:169-82. https://doi.org/10.1016/S0929 -1393(00)00093-7.

34. Vitousek PM, Howarth RW. Nitrogen limitation on land and in the sea: how can it occur? Biogeochem. 1991;13:87-115. https://doi.org/10.1098/ rstb.2013.0119.

35. Vitousek PM, Menge DN, Reed SC, Cleveland CC. Biological nitrogen fixation: rates, patterns and ecological controls in terrestrial ecosystems. Philos Trans R Soc B. 2013;368:1621. https://doi.org/10.1098/ rstb.2013.0119.

36. Zivcak M, Brestic M, Olsovska K, Slamka P. Performance index as a sensitive indicator of water stress in Triticum aestivum. Plant Soil Environ. 2008;54:133-9. https://doi.org/10.17221/392-PSE.

37. Zivcak M, Olsovska K, Slamka P, Galambosova J, Rataj V, Shao HB, et al. Application of chlorophyll fluorescence performance indices to assess the wheat photosynthetic functions influenced by nitrogen deficiency. Plant Soil Environ. 2014;60:210-5. https://doi.org/10.17221/73/2014-PSE.

38. Zivcak M, Olsovska K, Slamka P, Galambosova J, Rataj V, Shao HB, et al. Measurement of chlorophyll fluorescence in different leaf positions may detect nitrogen deficiency in wheat. Zemdirbyste-Agri. 2014;101:437-44. https://doi.org/10.13080/z-a.2014.101.056.

\section{Publisher's Note}

Springer Nature remains neutral with regard to jurisdictional claims in published maps and institutional affiliations.
Ready to submit your research? Choose BMC and benefit from:

- fast, convenient online submission

- thorough peer review by experienced researchers in your field

- rapid publication on acceptance

- support for research data, including large and complex data types

- gold Open Access which fosters wider collaboration and increased citations

- maximum visibility for your research: over $100 \mathrm{M}$ website views per year

At BMC, research is always in progress.

Learn more biomedcentral.com/submissions 